\title{
Academic Experience of International Students on Scholarships in Malaysian Universities: The Case of A Private University College
}

Adekalu Samuel Olutokunbo (Corresponding Author)

Postgraduate Student - Department of Professional Development and Continuing Education,

Faculty of Educational Studies, Universiti Putra Malaysia, Selangor Malaysia

E-mail: toksadekalu01@yahoo.co.uk

Ismi Arif Ismail Ph.D.

Department of Professional Development and Continuing Education, Faculty of Educational

Studies, Universiti Putra Malaysia, Selangor Malaysia

E-mail: ismi@putra.upm.edu.my

Turiman Suandi Ph.D.

Department of Professional Development and Continuing Education, Faculty of Educational

Studies, Universiti Putra Malaysia, Selangor Malaysia

E-mail: tj@upm.edu.my

Doi:10.5296/ijld.v3i6.4606

URL: http://dx.doi.org/10.5296/ijld.v3i6.4606

\begin{abstract}
The rate at which most organizations and institutions of learning offer scholarship and grant to attract international students is becoming competitive among citizens of the developing nations who seek to gain international education experience for better career opportunities and educational development. At present, Malaysia is fast becoming an educational centre for international students as the country has set a target by year 2020 to attract 200,000 international students from Africa, Asia and the Middle East and other continents of the world. It then becomes imperative to investigate the readiness of the country in terms of the provisions in place for achieving this laudable goal. It is with this intent that this study investigates the academic experience of international students on scholarships in Malaysian Universities. An in-depth interview was conducted among a group of international students in Malaysia with a particular focus on Petroleum Technology Development Fund (PTDF) scholarship recipients studying at a Private University College. The study revealed that, the scholars are generally satisfied and able to cope with the classroom teaching as well as academic huddles at Linton University College (LUC) while adapting to host challenges. They are able to comply with renewal of students' visa regulations in Malaysia. This study suggested among other things, an initiative such as recommendation to improve international student academic experience studying in Malaysian Universities with an effort to enhance their academic performance and career opportunities, when the scholars returned to their respective countries.
\end{abstract}

Keywords: Academic Experience, International Students, Malaysia, Scholarships.

\section{Introduction}

Recent challenges emanating from globalization remain one of the key factors propelling most government agencies and organizations to offer scholarships to citizens both at the local and international levels for the sole purpose of empowering them to become positive agents of 
change for the socio-economic development of the nation (Adekalu, Oludeyi, Genty \& Wolo, 2013). In the same vein, certain push and pull factors influence students to seek international academic experience. The push factor refers to those deterrent key elements that contribute to students' decision making process for choice of study destinations to seek higher education in countries other than their home countries. These push factors include, but not limited to: underfunding, poor educational systems, cultism and cult-related violence, bad institutional image, limited entry-level job opportunities, university staff misconduct and ineptitude caused by low wages, social and racial discrimination, unpleasant educational and immigration policy and a variety of political and socio-economic factors. While on the other hand, the pull factors refer to incentives that attract international students toward certain host countries and these can include: scholarship availability, quality of the education system, political ties, cultural and religious similarities, and the belief that holding an international education credential will help for better lucrative career opportunities and further educational empowerment (Adekalu \& Oludeyi, 2013; Skinner \& Shenoy, 2003).

The effort of the Malaysian government, under the Ministry of Higher Education (MoHE), to attract 200,000 international students by year 2020 may be a dream of reality since the existing international students have encouraging academic testimonies to share with the international communities in terms of teaching and learning experience gained. Coincidentally, it was revealed that, the requirements for ranking universities in terms of quality of education, availabilities of technology, infrastructures development, high impact universities research performance index, resources availability, faculty expertise, socially significant activities of graduates, international opinion/activities and rate of international students seeking for higher education experience in top best rated institutions of higher learning, among others, are some of the key factors, while Malaysia today, strive to have more international students in both private and public universities (Chong \& Amli, 2013). However, the growing numbers of outbound student-tourists under scholarship and self-sponsorship who are searching for educational empowerment and knowledge-boosting is striving most institutions of higher learning to strengthen their partnership and cooperation with the government, parents and international institutions/organizations and this have become the major nationwide movement in most countries' educational sectors (Adekalu \& Oludeyi, 2013; Bartram, 2007; Komives, \& Woodard, et al., 2003).

International students and their dependents have been confirmed to be essential citizenry in a country's higher education in the way of bringing substantial income to host institutions and contributing extensively to the host countries' intellectual, economic, political and socio-cultural development (Lee, 2007). In this regard, Komives (2003) further recommended that student affairs experts and consultants should increase their awareness and knowledge of international alliance and cooperation as part of their efforts to stay active in this ever changing and complex world of student academic experience. It is towards complementing this laudable goal that this study was conducted to answer the research questions of: First, to what extent do students on scholarship adjust to cope with classroom teaching, adapt to host community, comply with renewal of students' visa regulations during their stay in Malaysia? Second, to what extent does the whole academic experience gained by students, positively or negatively, influence students' academic and non-academic development?

Although there are substantial empirical studies that have been done in other countries with regard to international students, most of the research were focused on a particular aspect of problems of international students, such as advising relationships or mental health issues (Aida Hafitah \& Maimunah; 2007, Anh, 2010). Limited research has been done in the Malaysian context in terms of the experience of international students and the gap in the relevant issues regarding students with scholarships compared to the self-sponsored students, and the general experience of renewal of visa. These areas have not been thoroughly explored. Lavendran 
(2013) revealed the challenges faced by international students in renewing their students' visa in Malaysia and this is seen as a serious concern to stakeholders including governments of the international students, parents, other organizations/institutions which are involved with the students' academic status, i.e. scholarship sponsors, and potential international students of Malaysian institutions. With particular focus on academic experience of the international students under the sponsorship of Petroleum Technology Development Fund (PTDF) at a private university college in Malaysia, it is believed that, findings of the study will add to the existing body of knowledge in academic institutions.

\section{Literature Review}

There are substantial literatures on international students with different area of focus as determined by the interests, disciplines and socio-academic background of the researchers. Some literatures identified particular problems encountered by international students which include, but not limited to: choice of study destinations, modes of teaching and learning, loneliness and isolation, culture shock, adverse experience in the host country, lack of support, unrealistic family and self-expectations, meaningfulness of relationships with host nationals, a changing sense of identity, financial problems, alienation and crises at home (Adekalu \& Oludeyi, 2013; Deakins, 2009; Leask, 2009; Rosenthal et al., 2008; McClure, 2007; Mitchell et al., 2007; Neri \& Ville, 2007; Hanassab, 2006; Klomegah, 2006).

In the context of this paper, scholarship can be defined as an award of financial aid given to students to further their education within a stipulated period of time either at the local or international institutions of learning, which are mostly awarded by the government, international institutions/organizations or philanthropists, depending on location and institutions of choice. The beneficiaries, who are privileged to be sponsored based on selected criteria that reflect the values, terms and conditions of the award, are referred to as scholarship students or recipients. On the other hand, academic experience can be defined as knowledge acquired through learning, teaching and research, with other various extra-curricular activities that students engage themselves in, within academic environments. According to Adekalu \& Oludeyi (2013), international students are referred to as students who live and study in foreign countries. However, this study defines international students as those with different national identities such as background, cultural heritage, religion, race and gender who are eligible to have the minimum and maximum entry requirements and adequate resources to seek for educational empowerment outside the purview of their nation's boundaries from an approved academic programme that is recognised by the host institution and other educational authorities worldwide. In this regard, studying abroad may give a different lifestyle and set of experience for most international students and it is on this note that this study becomes imperative. Hence, most students entering a tertiary environment for the first time undergo a period of transition. This experience is heightened for international students (Guilfoyle, 2004; Burns, 1991).

However, Pires, et al. (2006) link the themes of social support and cultural identity in their research, submitting that ethnic communities in a host culture play valuable roles in aiding the transition experience. Bandura (2007) further supported that, students' successes are more likely to take place when students believe that their individual efforts matter, that is, when they believe they can exert significant influence or control over their academic and personal success. Meanwhile, student success is more probable when students find meaning or purpose in their college academic experience, such that, students perceive relevant connections between what they are learning in college and their current life or future goals. Although factors like lack of personal goals for the college experience may stand irrelevance in terms of the teaching method and curriculum (Levitz \& Noel, 1989; Noel, 1985).

Also, previous researches show that student involvement outside the classroom is a potent predictor of student retention. To buttress on this, students who have close interaction and 
effective communication with the academic and non-academic staff in their respective colleges in term of academic and other related matters may likely to persist the college experience suitable and memorable (Pascarella \& Terenzini, 1991, 2005). Most times, due to cultural difference both in academic and social aspect, some international students may experience being alienated (Banumathy \& Vikneswaran, 2008; Hooley \& Horspool, 2006). This may make students have proper orientations at the beginning of their studies in order to cope with life experiences to become successful when rethinking what they are learning compared with their previous experience.

\section{Research Methodology and Participants Location}

In this qualitative study, data were gathered through face-to-face in-depth interview with a total of 6 participants and semi-structured interview among undergraduate students who were on Petroleum Technology Development Fund (PTDF) scholarship scheme at a private university college. The number of participants was determined until the study reached its saturation point. The ages of the participants range between 19 to 30 years old. The interviews were facilitated through the use of voice recorder and writing materials and the data were further categorised and analysed until a set of themes are derived. The participants were interviewed in their campus hostels at the Linton University College in Malaysia between $28^{\text {th }}$ September to $13^{\text {th }}$ October 2013. Below is the profile of the participants:

Profile of Participants

\begin{tabular}{|c|c|c|c|}
\hline Participants & Gender & Course of Study & Duration of Stay \\
\hline P1 & Male & Software Engineering & 1 year and 7 months \\
\hline P2 & Female & Business Information Systems & 1 year and 5 months \\
\hline P3 & Male & Civil Engineering & 1 year and 7 months \\
\hline P4 & Female & Software Engineering & 1 year and 7 months \\
\hline P5 & Male & Software Engineering & 1 year and 7 months \\
\hline P6 & Male & Mechanical Engineering & 1 year and 10 months \\
\hline
\end{tabular}

\section{Results and Discussions}

1. Classroom Teaching

Question One. How do you cope with the Classroom Teaching at LUC?

P1.

"The classroom teaching here at LUC, Malaysia is good, nice and comfortable for every student because, the classrooms are well equipped with teaching facilities. There are chairs and projectors in all classes. The number of students in each class is not that much that will affect the teaching of the students. Also the lecturers are qualified and they teach their students very well".

P2

"The classroom teaching is good but it depends on the kind of lecturer, because here at LUC we are able to interact with our lecturers like they are our friends. Unlike other countries where lecturers are seen as "gods". When students ask question the lecturers give relevant answers"

P3

"The method of teaching here at LUC is encouraging. The lecturers have been giving helping hands not only to me but to other students in the class \& sometimes the lecturers organise additional extra classes to enhance our knowledge in the areas where we have difficulties".

P4 
"The classroom teaching is quite good and motivating. I do feel inspired to develop my career in academics. I have access to technology \& other instructional materials in my college and this has helped me a lot to improve my learning ability".

P5

"With the facilities provided the classroom teaching are in order. Some of the lecturers were unable to explain some certain things that are experimental issues whereas they focus on the theoretical part which are some of the lapse in my experience over here at LUC.... But the classroom teaching generally is worthy to be embraced which is good in learning something worldwide".

\section{P6}

"I like sitting at the front during lectures... the lecturers do encourage us to listen first before writing... As for me the classroom teaching is very good... I like to listen to the lecturers when teaching \& try to understand before writing..."

Most of the participants reported that, the classroom teaching at LUC is very good and encouraging. The above statements revealed that, lecturers at LUC teach very well and make effective use of instructional material. The practical experiences the lecturers have served to help the students comprehend well in the class P1. It was further revealed that, the lecturers gives suitable answers to questions and are always ready to help outside the purview of classroom teaching by organizing extra tutorial classes to support the students in the presence of academic doubt P3. These findings compliment research done by (Pascarella \& Terenzini, 1991, 2005) on student retention. This is because, the level of interpersonal relationship and flow of academic communication between the students and lecturers at LUC indicate that not only that the students perceive the academic experience suitable but also the lecturers who find passion for teaching and research to put the students on the right path as this may stand as unforgettable memory to both the lecturers and the students.

\section{Renewal of Student Visa}

Question Two: What are your experiences in renewing your student visa during your schooling?

P1

"I can say it is 50-50. Student visa processing here in Malaysia goes two ways. Some students get their visa renewed without time delay while for other students, like myself; there is always long time delays in getting my student visa renewed... I can't say whether the problem is from my college or Malaysia Immigration Department, but with the new process now I am hearing from my colleagues that the process is been simplified than before"

\section{P2}

"I have never experienced any difficulty regarding my student visa renewal. As a scholar, I try to fulfil the requirements of Malaysia Immigration Policy by having $80 \%$ attendance with the CGPA of 2.00 and above... also, the increments in renewal of student visa is of no serious concern to me because as a Scholar all fees regarding my study is cater for by PTDF... So it is quite easy for me"

\section{P3}

"I think the Malaysian Government need to make some measure in this area of renewal of student visa... Here at LUC the management are trying in making sure the student visa pass are renewed within the period of 1 to 2 months.

\section{P4}

"The process is very rigorous.... As a scholarship student I should find my visa renewal easy... However, Malaysia Immigration Department are trying their best, if there are any doubt about my academic status they can refer to LUC or PTDF" 
P5

"I think this is an issue that keeps recurring over and over again and is a dynamic one... at LUC before, it is quite easy to renew student visa but now everything has become cumbersome with the new Malaysia Immigration Policy...Like me and some other students are asked to conduct medical test before we could renew students visa \& the process is tedious and time consuming" P6

"I am always quite lucky... ever since I have been submitting my passport to renew my student visa I have been receiving my passport back with visa in less than 1 month. I have not really experienced any difficulty in renewal my student visa.

The results show that, some participants find renewing their student visa stress-free P2 and P6 while some do have certain difficulties which pose challenge to them to renew P1, P3, P4 and P5. At present, Malaysia is fast becoming an educational centre attracting students from Asia, Africa and the Middle East and other continents of the world. But currently, international students are finding it difficult to obtain visas or renew existing ones. The challenges encountered by international students for visa renewal, as revealed by the participants, is an indicator to support the position of Larendran (2013), about the level at which scholarship and self-sponsored foreign students currently experience tedious and rigorous stress in renewing their student visa due to the new Malaysian education and immigration policy. However, the argument raised by some international students in Larendran (2013) update regarding the unpleasant increment in visa fee charge by institutions as demanded by Education Malaysia Global Services (EMGS), which is the sole agency processing and issuing student visas, is of no financial distress to the participants as findings from this study has shown that, students who are on PTDF scholarship scheme at LUC revealed that visa and other related fees are cater for by their organization and their expectation to renew their visa is to fulfil the requirement of Malaysia Immigration Policy which in maintaining 80\% attendance with the CGPA of 2.00, using the Malaysian Education Grading System as said by P2. Conceivably, Carroll \& Ryan (2005) in their opinion posited that, international students should cope with challenges encountered without social and emotional support mechanism as it may have implications towards academic failure upon their visa status.

\section{Adjustment}

\section{Question Three: How do you adjust to the academic life in LUC? P1}

"The academic life here at LUC is much easier while in some areas it is very stressful... It is quite easy for me to adjust to the academic setting in such a way that, the system provides more practical than theoretical aspect... as software engineering student, I find it very easy to understand my courses because of the practical aspect I am being exposed too"

\section{P2}

"At LUC, it is very easy to adjust to the academic life. The lecturers are friendly and nice... I like the self-learning approach and with the support of the internet I research \& make findings which I find interesting \& as BIS student, I don't always feel comfortable if I don't work with my laptop everyday"

\section{P3}

"I think the academic life at LUC is quite encouraging \& good if am to say the truth. I am able to cope $\&$ adjust to the academic system with the use of technology I am exposed to now I can network globally"

P4

"I am able to adjust to the academic life here at LUC very easily because the method of 
teaching here at LUC is English Language \& the environment is conducive for learning"

P5

"The ability of a man to adjust to any environment is one of his attributes. As for me, it is a favourable one, though, the time zone varies, time to sleep and time to go for lectures... I have been able to adjust quickly at LUC because I have to make my academic plans"

P6

"When I first came to Malaysia here at LUC to study Mechanical Engineering it was challenging for me. The first assignment I did, I was not confortable... But, I work closely with my lecturers and the senior students in term of my difficulties and they tried to advise and put me on the right path. Today everything is fine and I am always grateful to God"

Based on the discussions above, almost all the participants interviewed revealed that, they adjust easily to the environment and academic life at LUC which they find very nice and interesting. According to Brown Holloway (2008), adjustment of international students to new academic life style in foreign countries can be a self-motivated and multifaceted process. This is because international students who seek to have educational empowerment should bear in mind the various challenges that are attached to the success they are bound to experience before the attainment of their desired goals. However, since the participants of this study are funded by scholarship and have all what it take to study in terms of the benefits that accomplished their scholarship education as provided by their sponsored and provision package provided to them by the institution they likely to cope and or adjust to the academic life in Malaysia and feel greater pressures to academic success.

\section{Host Community}

\section{Question Four: How do you cope with the host community?}

P1

"The weather here in Malaysia is adaptable for me. The cost of living is almost the same with my home country in terms of the food I eat and the materials I use for my day to day activities. Also the people in the host community are friendly and accommodating"

$\mathbf{P 2}$

"It doesn't take me much time to cope and adjust to the host community because Malaysia weather looks like that of my home country compared to some western countries. The kind of people I met when I came to Malaysia, the Malays, Chinese, Indians, Iranians they are very friendly and accommodating. This makes it easy for me cope in the environment and meeting so many Africans here at LUC I feel more comfortable and I wish there were ways I could pay the university back"

\section{P3}

"The people here at LUC makes the environment conducive for learning, so I am able to cope and with the response I am hearing from my friends they also testify to it that the environment is friendly and I think that is okay"

\section{P4}

"The host community have been good, am coping very well to the glory of Almighty God. I adapt quickly with the weather condition and the people I meet here are very friendly and nice and accommodating which I find very interesting"

\section{P5}

"The environment is good and friendly, I must recommend that, so I cope very fast, because I prepared myself before coming to Malaysia for my studies and wherever I find myself to study in the world I would like to adapt and cope irrespective of the situation. The local and fellow international students are friendly. In one sentence, the host community is good"

\section{P6}


"When I first came to Malaysia I find it very difficult to cope seeing many Africans. But when I started going for lectures I met with the Malays, Chinese, and Indians, Iranians, Pakistanis \& other nationalities, I felt more comfortable, so the environment is nice for academic purposes and with God on my side I am willing to positively give back to the host institution".

The results show that most of the participants were able to cope with the host community. It was further testified by the participants that the environment is conducive for learning and the people in the community are good and accommodating most especially the Malays, Chinese, Indians and other nationalities. This, of course, is owing to the adequacy of facility and enticing academic environment where the participants study. Some of the students also expressed their commitment to contribute positively to the upkeep of both the university and the host country. This finding has earlier been echoed in the study of Adekalu and Oludeyi (2013) that the large portion of international students and youths resort to flying abroad to further their studies in institutions where they can be exposed to purely cultured, standardized and quality academic experience. Hence, it soon becomes easy for them to be willing to contribute meaningful quota to the development of the host institution or nation.

\section{Knowledge Gained}

Question Five: What impacts do your experience as students make in your life? Positive, Negative or both?

P1

"I can say is both, I will like to start with the positive aspect, first, I had the experience to travelled abroad to study. Second, I had the experience of adapting to new environment that is different from my home country. Third, I had the experience to live with many people of different nationalities, cultures and norms here in Malaysia. Forth, I had the experience of living away from my Family which made me to be more confident $\&$ independent. For the Negative aspect, my understanding of practical approach of learning here at LUC have diminished my orientation of understanding of theoretical courses"

\section{P2}

"My academic experience so far in Malaysia is positive I don't know of other students because here at LUC am expose to more of practical way of learning \& the education system in Malaysia is very easy compare to some developing countries system of education"

\section{P3}

"I had positive experience because here I can do things on my own and I can work together with my fellow students as a group"

\section{P4}

"For me is both, the positive aspect is that I am happy to study software engineering and been a scholar living comfortable, I have never think of tuition fees. The academic environment also at LUC is conducive for learning and with the usage of technology has made positive impact in my life. The only negative experience I had is living far from my family because I love been with my parents back in my home country"

P5

"The impact so far is positive, coming down to Malaysia to study has really reshaping my life positively"

P6

"To me is positive. My life has change socially and academically. I always give thanks to God, my parents and organization am representing here at LUC. Because is always my dream to study abroad and now is no more a dream but a reality..." 
The above findings shows that, participants' category (P2, P3, P5, \& P6) have positive experience which has transformed their life positively and participants' category (P1\& P4) said to have both positive and negative experience in the course of their study in Malaysia. What is however observable is that many international students experience in foreign higher institutions of learning having more positive impact on them than negative. The most recurring theme in the positive aspects of their experience as international students is that they are made to be self-reliant, independent and bold to face life challenges on their own without being influenced by parents or relatives who would rather pamper them. This alone prepares them for leadership qualities needed to scale through future challenges. Little wonder why the study of Adekalu and Oludeyi (2013) contends that many international students who graduate from U.S. universities, for example, participate in development agencies such as the United States Agency for International Development (USAID) that further help in upholding the nation's ideals. The only few negative experience may however be considered as 'normal' because it only has to do with emotional attachment to families and relatives. For instance P5 only feels lonely because of the distance from family back at home. Many researchers have alluded to this aspect of international students' experience while studying. Banumathy and Vikneswaran, (2008) as well as Hooley and Horspool, (2006) had earlier show that most times, due to cultural difference both in academic and social aspect, some international students may initially experience being alienated. Most conclusions to such feelings of isolation by the international students are that 'the passing of time' will kill such feelings. It is only psychological and like a normal fever for any persons who is new to the changing environment.

\section{Conclusion and Recommendation}

Based on the findings from this study, it can be concluded that international students who were on Petroleum Technology Development Fund (PTDF) scholarship scheme at a private university college in Malaysia have more positive academic experience in leaving their home country to study abroad. The level at which they adjust to the academic life in Malaysia is encouraging taking into consideration the teaching methods, lecturers friendliness, the manner in which the people in the host community accommodate and welcome international students. It is however worthy to note that, this study has been designed and carried out with specific purpose of looking at international students' academic experience with particular focus group of scholarship students at one university and this cannot be claimed to be in any way generalizable to other universities and students that are self-sponsored. Further research areas of interest on international students can be conducted by increasing the sample size and institutions location. Nevertheless, among the initiatives that the Malaysia government and the host university can consider for policy adjustment are as follows:

1. Host institutions should provide international students with informative and detailed welcoming package that explains the academic and the non-academic matters so that students can prepare themselves sufficiently. This is because, the current study, as well as the studies of Komives (2003) has shown that, student affairs practitioners should enhance the awareness and knowledge of international students and other parties that are saddle with the responsibility of educational programmes with to efforts of given the best needed services to the students. This will help to boost the students' morale for more positive attitude towards study and to be good ambassadors to both home and host countries.

2. A supportive international office is very crucial as international students face many challenges that are sometimes general and sometimes unique in nature. A 'one size fits all' procedure may help in routine procedure like passport renewal or other immigration matters. This becomes necessary as findings from this study show that, renewal of student visa pass is one of the current challenges faced by International students in Malaysia. Participants in this 
study revealed that there is some level of imbalance in the operations of all the agencies and parties who are saddle with the responsibilities of renewing the students' visa. However, as for things which are more personal in nature, a more personal intervention from the officers really will help in supporting the students with their possible best if need arises. International Student Counselling Unit (ISCU) may be established in the university to help international students on personal worries. This ISCU will also serve as veritable source of further more-personal information that will be valuable in guiding policy adjustment aiming to better the life of present and future international students.

3. University academic experience without socialization is, beyond doubt, invalid and incomplete. The host institution should enhance the international student ecosystem through activities that nurture diversity management in campus and encourage interfacing among both local and international students. The extra curriculum activities such as intercultural display among students of different nationalities, inter-institutional sports competitions and knowledge sharing forum are parts of the experience that students should be exposed to. This will go a long way in keeping the students physically and mentally sound.

4. The Malaysia Government should continue to show more than perceive interest to invest heaving on the quality of education and infrastructures development of the nation by taking into consideration UNESCO recommendation of $26 \%$ of the total budget of the nation should be invest on education as this may help the nation expectation of attracting 200,000 International students by year 2020 a dream of reality as finding from this study revealed the level of satisfaction and academic testimonies of the international students as the current study as well as the studies of Adekalu \& Oludeyi, (2013) as well as Lee (2007) revealed the benefits international students brings to the host countries is a predictor to achieve the Government Transformation Programmes (GTP) and Economic Transformation Programme (ETP) which aimed to transform the nation into high-income economy by year 2020 .

\section{Acknowledgement}

The corresponding author sincerely appreciates the effort of Associate Professor Dr. Ismi Arif Ismail the Deputy Dean (Research and Graduates Studies) Faculty of Educational Studies, Universiti Putra Malaysia and Professor Dr. Turiman Suandi Department of Professional Development and Continuing Education, Faculty of Educational Studies, Universiti Putra Malaysia for making this academic paper largely successful. Special thanks to all the respondents who create time out of their busy schedule to participate in this research. Big thanks to fellow researchers which academic contributions are duly cited in this work. In addition, an esteem highest regards to the editors and reviewers of Macrothink Institute, USA in collaboration with Human Resource Management Academic Research Society (HRMARS) who successfully published this research work.

\section{References}

Adekalu S. O., Oludeyi O S., Genty K I., \& Wolo A. (2013) Petroleum Technology Development Fund (PTDF) Mandates and Human Capacity Development in Nigeria: Benefits for Nigerian Youths. International Journal of Research in Management Issue 3, Vol.5 pp 67-77.

Adekalu, S. O., \& Oludeyi, O. S., (2013) Edutourism: The Nigeria Educational Challenges and International Students Choice of Study in Nigerian Universities. International Journal of Academic Research in Progressive Education and Development. Volume 2, Issue 4. Pp. 53-63

Aida Hafitah M. T. \& Maimunah I. (2007). Cross- Cultural Challenges and Adjustments of Expatriates: A case Study in Malaysia. Alternative Turkish Journal of International Relation. Vol. 6 pp 72-99 
Anh Le, (2010). Making the Great Journey: International Students' experiences at the University Of Nebraska-Lincoln. Educational Administration. USA.

Bandura, A. (1997). Self-efficacy: The exercise of control. New York: Freeman \& Co.

Banumathy, D. \& Vikneswaran, N. (2010). In Sarjit, K., Morshidi Sirat \& Azman Norzaini. 2010. (ed.). Globalisation and Internationalisation of Higher Education in Malaysia. Pulau Pinang: Penerbit USM.

Bartram, B. (2007). The sociocultural needs of international students in higher education: A comparison of staff and student views. Journal of Studies in International Education, $11(2), 205-214$.

Brown, L., \& Holloway, I. (2008). The Adjustment Journey of International Postgraduate Students at an English University: An ethnographic study. Journal of Research in International Education, 7(2), 232-249.

Burns, R. B. (1991). Study and stress among first year overseas students in an Australian university. Higher Education Research and Development, 10 (1), p. 61-77.

Chong P. Y. \& Amli H. A. M., (2013). International students' learning experience at private higher education institutions in Malaysia. Proceeding of the Global Summit on Education. pp. 298-312

Deakins, E. (2009). Helping students' value cultural diversity through research-based teaching. Higher Education Research \& Development, 28(2), 209-226.

Guilfoyle, A.M. (2004). Exploring the Spaces in-between Institutional Services Provided and International Postgraduate Student Experiences. 18th IDP Australian International Education Conference. Sydney, pp 1-11.

Hooley, T. \& Horspool, P. 2006. Two sides of the same story? Staff and student perceptions of the non-native speakers experience of the British academic system. The East Asian Learner 2(2) Pg. 1-10.

Klomegah, R. Y. (2006). Social factors relating to alienation experienced by international students in the United States. College Student Journal, 40(2), 303-315

Komives, S., \& Woodard, D., et al. (2003). Student services: A handbook for the profession. San Francisco: Jossey-Bass.

Lavendran, G. (2013), Foreign students in a dilemma: FMT News 6th of September, 2013. Received online on $16^{\text {th }}$ November, 2013 from http://www.freemalaysiatoday.com/category/nation/2013/09/06/foreign-students-in-adilemma/

Leask, B. (2009). Using Formal and Informal Curricula to Improve Interactions between Home and International Students. Journal of Studies in International Education, 13(2), 205-221

Lee, J. J. (2007). Neo-racism toward international students. About Campus, 11(6), 28-30.

Levitz, R., \& Noel, L. (1989). Connecting students to institutions: Keys to retention and success. In M. L. Upcraft, J. N. Gardner, \& Associates, The freshman year experience (pp. 65-81). San Francisco: Jossey-Bass.

McClure, J. W. (2007). International graduates' cross-cultural adjustment: Experiences, coping strategies, and suggested programmatic responses. Teaching in Higher Education, 12(2), 199-217

Mitchell, S. L. Greenwood, A. K., \& Guglielmi, M. C. (2007). Utilization of counselling services: Comparing international and U.S. college students. Journal of College Counseling, 10(2), 117.

Pascarella, E. T., \& Terenzini, P. T. (2005). How college affects students, Volume 2: A third decade of research. San Francisco: Jossey-Bass. 
Rosenthal, D. A., Russell, J., \& Thomson, G. (2008). The health and well-being of international students at an Australian university: Higher Education: The 101 International Journal of Higher Education and Educational Planning, 55(1), 51-67.

Pires, G., Stanton, J. \& Ostenfeld, S. (2006). Improving Expatriate Adjustment and Effectiveness in Ethnically Diverse Countries: Marketing Insights Electronic journal. Cross Cultural Management. An International Journal, Vol 13, No.2 156-170.

Skinner, K. G., \& Shenoy, A. (2003). International students: In J. W. Guthrie (Ed.), Encyclopaedia of education; (2nd ed.). New York: Macmillan Reference USA. 